\title{
The conservation status of Sabellaria alveolata (L.) (Polychaeta: Sabellariidae) reefs in the Bay of Mont-Saint-Michel
}

\author{
N. Desroy ${ }^{1, *}$, S. F. Dubois ${ }^{2}$, J. Fournier ${ }^{3,4}$, L. Ricquiers ${ }^{5}$, P. Le Mao ${ }^{1}$, L. Guerin ${ }^{5}$, D. Gerla ${ }^{1}$, \\ M. Rougerie ${ }^{1}$, A. Legendre ${ }^{1}$
}

\footnotetext{
${ }^{1}$ IFREMER, CRESCO, Laboratoire "Environnement et Ressources Finistère-Bretagne Nord", Dinard, France

2 IFREMER, DYNECO Laboratoire d'Ecologie Benthique, Technopôle de Brest-Iroise, Plouzané, France

${ }^{3}$ CNRS UMR 7208 BOREA, Muséum National d'Histoire Naturelle, Paris cedex 05, France

${ }^{4}$ Present address: CNRS UMR 6042 GEOLAB, Clermont-Université, Clermont-Ferrand cedex, France

${ }^{5}$ Muséum National d'Histoire Naturelle, CRESCO, Dinard, France
}

*: Corresponding author : Nicolas Desroy, email address : Nicolas.Desroy@ifremer.fr

\begin{abstract}
:
Reefs built by the annelid worm Sabellaria alveolata in the Bay of Mont-Saint-Michel (France) are the most extensive intertidal biogenic structures within Europe. Before and after mussel farming extensions, a study designed to provide a biological health index of the Sainte-Anne reef (223 ha) was carried in 2001 and 2007 to serve as an easy-to-use management tool and to ensure endangered reef portions were properly targeted and protected.
\end{abstract}

Coupled physical and biological parameters were included in a spatial Health Status Index (HI). A spatial and temporal mapping survey of the HI showed a continuous deterioration of the reef's state of health, particularly in its central part. This degradation correlates with the colonization of the Pacific oyster Crassostrea gigas and with increasing silt deposits on the reef.

A combination of several factors is likely to explain such rapid reef deterioration: (1) an increase in trophic competition between cultivated and wild suspension-feeders that is detrimental to the annelids; (2) a modification in the hydrodynamics and consequently in sedimentary patterns leading to an increase in silt deposition; and most importantly (3) an increase in recreational harvesting of oysters and associated reef trampling, resulting in reef fragmentation.

Understanding the parameters that influence the reef dynamics is necessary in order to help efficient and effective management and policy focusing on the conservation status of large biogenic structures.

Keywords : Sabellaria alveolata ; biogenic reef ; health status ; biological indicator ; shellfish farming ; recreational fishing activities 


\section{Introduction}

Biogenic reefs offer a large diversity of micro-habitats for a wide range of sessile and vagile macrofaunal species. As specified by Holt et al. (1998), organisms other than cnidarians, notably sponges (de Voogd, 2006), mollusks (Rodney and Paynter 2006), polychaetes (Moore et al., 1998; Pawlik, 1998; Dubois, 2003) or bryozoans (Cranfield et al., 2003) are able to build reefs in certain environmental conditions. Many of these species form highly variable physical habitat and along a "reefiness" gradient (Hendricks and Foster-Smith, 2006) not all of them worth be calling reef. A number of sabellariidae (annelida: polychaeta) species are known to form extensive reefs, such as Phragmatopoma californica in California, Phragmatopoma caudata in the Atlantic coasts of the Americas, Idanthyrsus spp. in equatorial regions, Gunnarea capensis in South Africa and Sabellaria alveolata along European coasts (Achary, 1974; Wilson, 1971).

Biogenic reefs play key functional roles in ecosystems and contribute to physical and biological process, by (1) stabilizing the substrate and trapping sediment, (2) providing a diversity of microhabitats (e.g. crevices) and increasing available spaces for new species to colonize, and (3) accumulating faeces, pseudo-faeces and other organic deposits that may be important food sources for other organisms (Holt et al., 1998). As a consequence, fauna and flora associated with biogenic reefs are very often species-rich, at least in terms of macrofauna, and generally contrast with the surrounding areas where diversity and abundances are lower. Along the European coast, the largest biogenic reefs are constructed by Sabellaria alveolata. These bioconstructions can have two forms: encrusting colonies adhering to rocks, very common at the mid level of the intertidal zone and, more rarely, reefs developing on soft-bottom and forming large banks in the intertidal zone. The largest Sabellaria reef (225 ha) is found in the Bay of Mont-Saint-Michel in France (Dubois et al., 2002; Fournier et al., 2010).

Whereas historical studies focused on the biology of $S$. alveolata [reproduction, larval development and behaviour (see Wilson, 1929, 1968 and 1970), recent research works were dedicated to the ecological and functional role of the reef they constitute. As shown by Dubois et al., (2002) in the Bay of Mont-Saint-Michel, biodiversity associated with S. alveolata reefs is an order of magnitude higher than the surrounding soft bottom communities and host unique species assemblages, composed of species originated from other coastal and deeper environments.

Sabellaria reefs are also highly vulnerable structures and subject to various direct and indirect anthropogenic pressures (e.g. Dubois et al., 2002; 2006; Le Cam, 2011). In 2006 the mussel aquaculture concessions in the Bay of Mont-Saint-Michel were spatially extended. Consequently, the Sabellaria reefs were surrounded by intensive mussel cultivations, and susceptible to be indirectly degraded by smothering under Mytilus edulis faeces and pseudo-faeces or by the settlement of mussels on the reef, which subsequently break up the surface as they grow. In addition, reefs are exploited at spring low tides for settled oysters and mussels (Dubois et al., 2006) despite strong evidence that fishing and associated trampling are seriously damaging fragile intertidal habitats, such as reef (Dubois et al., 2002) or seagrass (Eckrich and Holmquist, 2000) habitats.

With the Council Directive 92/43/EEC on the Conservation of natural habitats and of wild fauna and flora (Habitats Directive) implementation in the Bay of Mont-Saint-Michel, the protection and conservation of Sabellaria alveolata reefs (habitat type 1170 "Reefs"), identified as being of rare biological and patrimonial heritage, became a major environmental issue. A better understanding of the contribution to biodiversity, and in particular the role of reef-builders as ecosystem engineers, would help to promote the conservation of biogenic reefs (Godet et al., 2008; Holt et al., 1998). The primary aim of this study is hence to determine the health status of the reef in the Bay of Mont-Saint-Michel in 2007. To address this issue, a monitoring protocol was designed and a health index was developed to determine the condition status of the reef. Results obtained in two sampling campaigns (2001 and 2007) were compared to accurately describe the reef status 
evolution and provide valuable information to stakeholders when determining adapted conservation strategies.

\section{Material and methods}

\subsection{Study area}

The Sabellaria alveolata reefs reach their maximum size in the Bay of Mont-Saint-Michel. There are two main Sabellaria reefs in this Bay: the Champeaux reef (29 ha, as measured in 2001) and the Saint-Anne reef (225 ha, as measured in 2001). The current study focused on the larger reef (Saint-Anne), situated in the southern part of the Bay at $48^{\circ} 38^{\prime} 700 \mathrm{~N}$ and $1^{\circ} 40^{\prime} 100 \mathrm{~W}$ (Figure 1 ).

The reef complex formed by S. alveolata is located at the edge of the two joint hydro-sedimentary systems. The central part of the Bay, which is characterized by high bioclastic content (25\% to $95 \%$ ), shows a gradual decrease of mean grain size from the subtidal to the intertidal zone. Sedimentation rates are higher ( $3 \mathrm{~mm}$ to $25 \mathrm{~mm} / \mathrm{year}$ ) in the intertidal zone and tend to decrease seawards (Bonnot-Courtois et al., 2004, 2008).

The Saint-Anne reef is made up of three main sub-reefs (named A, B and C) aligned in parallel to the $0 \mathrm{~m}$ line and facing intensive mussel cultures (Figure 1). Since 2003, new concessions were granted, in an effort to restructure the activity in close proximity to the reef.

\subsection{Reef dynamics}

Different morphological stages, as defined in Dubois et al. (2002) characterise the reef dynamics. The settlement of young recruits leads to isolated ball-shaped structures, which fuse as they grow to form barriers (named coalescent ball-shaped structures) and then platforms, which are considered the climax status. Through natural or anthropogenic disturbance, structures can regress toward degraded forms (named degraded ball-shaped structures or degraded platforms depending on the initial stage).

\subsection{Sedimentary and biological data collection}

In order to assess differences between the reef and the surrounding sediments, we used a stratified sampling design for sediment samples. We collected sediment samples in the fore-reef (2001: $n=11 ; 2007 n=11)$, inside the reef $(2001: n=15 ; 2007 n=15)$ and the back-reef $(2001$ : $n=12 ; 2007 n=12$ ) area both in March 2001 and February 2007. The fore-reef corresponds to the sand bank and the sand ridge (sea ride) located in front of the reef (Figure 1). The reef area corresponds to the sand bodies located within the reef complex. The back-reef area corresponds to the sedimentary extent located behind the reef (landward). Sediment samples were collected over a short period of time (3 days in 2001 and 1 day in 2007) during low water spring tides. Each sediment samples consisted of a core for sediment characterisation (10 $\mathrm{cm}^{2}, 10 \mathrm{~cm}$ deep), and a positioning information from a GPS, plotted into a GIS (Geographic Information System).

A coupled complementary sampling protocol was applied in 2001 and 2007 for biological sampling. A regular grid consisting of 196 squares (each $75 \times 75 \mathrm{~m}$ ) was drawn from an aerial orthophotograph of the reef (the 2001 and 2007 studies used images from 1999 and 2002, respectively) (Godet et al., 2009). Each grid cell was visited during field studies carried out in spring 2001 and 2007, during low water spring tide. New squares were added when the reef extension differed from the aerial view. For each grid cell, several parameters related to the physical structure of the reef were scored: the percentage of the total reef cover (scoring from 0 for 
absence to 10 for $100 \%$ of cover), the ratio of each developmental stage of the reef (scoring 0 for absence to 10 for $100 \%$ of cover) from the pioneer isolated ball-shaped structures to the degraded forms, and the fragmentation level (scoring from 0 to 10, as detailed in Figure 2). The sediment feature associated to each grid was also recorded. Moreover, within each $75 \times 75 \mathrm{~m}$ mesh, three quadrats of $1 \mathrm{~m}^{2}$ were used to randomly collect additional information from the reef surface, including the reef elevation as well as the density and percent cover (scoring from 0 for absence to 10 for $100 \%$ ) of the two main epibionts colonizing the reef, i.e. oysters Crassostrea gigas oysters and mussels Mytilus galloprovinciallis.

\subsection{Data analysis}

In order to simplify the result analysis, the reef was divided into three sub-reefs (A, B and C, Figure 1). Sediment samples were washed with distilled water, given 24 hours for particle settlement, and decanted. Sediments were then dried at $70{ }^{\circ} \mathrm{C}$ for $24 \mathrm{~h}$ and approximately $100 \mathrm{~g}$ were sieved through AFNOR standard sieves (with mesh sizes of 2.5, 2, 1.6, 1.25, 1, 0.8, 0.63, 050, 0.40, $0.315,0.25,0.20,0.16,0.125,0.100 \mathrm{~mm}, 80,63,50,40$ and $<40 \mu \mathrm{m})$. Each size fraction was weighed and the results expressed as a percentage of the total sample weight. Sedimentary parameters were determined by performing grain-size analyses on raw data through the Gradistat v. 4.1. program (Blott and Pye, 2001) modified by Fournier for AFNOR use (unpublished data), based on the Moments method using the Folk and Ward (1957) classification.

Differences of mean grain-size $\left(\mathrm{M}_{\mathrm{G}}=\exp \left(\ln P_{16}+\ln P_{50}+\ln P_{84}\right) / 3\right)$ and mud $(<63 \mu \mathrm{m})$ between years and sites (fore-reef, reef, back-reef) were tested by using parametric tests with R v. 2.13.0. (R Development Core Team, 2011). The assumptions of normality and homogeneity of variances were verified by the Shapiro and Bartlett tests, respectively.

Biological and reef physical and morphological data collected to characterize the reef status were processed with the software Surfer 8. For the reef elevation and the density/degree of epifaunal covering, , mean values were used to draw distribution maps and to test for statistical differences. The relationships between reef parameters measured in 2007 were tested using the Spearman rank correlation coefficient (Scherrer, 1984) and changes between 2001 and 2007 were analysed with a non-parametric Wilcoxon test for dependant samples (Scherrer, 1984). Basic parameters were tested for all squares of the grids defined in $2001(n=213)$ and $2007(n=198)$ and health status change was considered only for common grid cells $(n=160)$.

\subsection{Definition of Health status index (HI)}

To define the vitality status of the reef and its change since 2001, we suggest here a Health Status Index $(\mathrm{HI})$, integrating physical characteristics of the reef and reflecting its dynamics:

$H I=F D+(I B+C B+P-D I B-D P-O C-M C) \times R C$

where $\mathrm{FD}=$ Fragmentation degree score, $\mathrm{IB}=$ Isolated Ball-shaped structure cover score, $\mathrm{CB}=$ Coalescent Ball-shaped structure cover score, $\mathrm{P}=$ Platform cover score, $\mathrm{DIB}=$ Degraded Isolated Ball-shaped structure cover score, $\mathrm{DP}=$ Degraded Platform cover score, $\mathrm{OC}=$ Oyster Cover score, $\mathrm{MC}=$ Mussel Cover score and $\mathrm{RC}=$ total Reef Cover score (necessarily $>0$ ). The dominance of IB, CB and $\mathrm{P}$ as well as a high $\mathrm{RC}$ value and a low fragmentation are a sign of extension and of positive reef dynamics.

This index can then be expressed as an ecological status, as defined in ecological quality ratios (EQR) by expert judgement (Table 1). Three ecological statuses were used: good (up to 20), intermediate (between 20 and 2.5) and bad (below 2.5) Extreme values [positive (110) and negative (-200)] remain theoretical and have never been observed on S. alveolata reefs. 


\section{Results}

\subsection{Sedimentary changes}

In the whole reef area, the mean grain size of surrounding sediment was significantly higher in 2001 (595 $\mu \mathrm{m}, n=38)$ than in $2007(464 \mu \mathrm{m}, n=38)$ (t-test: $\left.\mathrm{t}_{(75)}=-32.3261, p=2.2 \mathrm{e}-16\right)$. The percentage of silt $(<63 \mu \mathrm{m})$ in 2001 was significantly lower $(4.66 \%, n=38)$ than in $2007(8.74 \%$, $n=38)$ (t-test: $\left.t_{(75)}=-1183.975, p=2.2 \mathrm{e}-16\right)$ (Figure 3). The heterogeneity of the sediments in the reef area was confirmed with an one-way ANOVA computed among the fore-reef, reef and backreef zones $\left(F_{(2,73)}=7.6246, p=0.0009\right)$. A HSD Tukey test showed that the fore-reef zone was significantly different from the back-reef zone $(p=0.02)$ and that the reef zone was significantly different from back-reef zone $(p=0.0008)$, which validated the hypothesis that the reef had a barrier effect.

The decrease in mean grain-size for surrounding sediments and the silting-up of each sub-unit was also significant. The fore-reef, reef and back-reef zones were compared separately between 2001 and 2007 (Table 2) with paired t-tests. In the fore-reef zone, sediments were coarser in 2001 $(753 \mu \mathrm{m})$ compared to $2007\left(369 \mu \mathrm{m}, p=2.210^{-16}\right)$. The percentage of silt in $2001(3.00 \%)$ was significantly lower than in $2007(8.39 \%)\left(p=2.210^{-16}\right)$. More subtle differences were found in mean grain-size and silt percentage in the central reef zone. The mean grain size was $703 \mu \mathrm{m}$ in 2001 and $693 \mu \mathrm{m}$ in 2007 . The difference was significant $\left(p=8.3710^{-16}\right)$. A significant but weak increase of silt occured in this zone $\left(4.25 \%\right.$ in 2001 and $5.19 \%$ in $\left.2007 ; p=2.210^{-16}\right)$. For the back-reef zone, we found a significant decrease of mean grain size between $2001(313 \mu \mathrm{m})$ and 2007 (265 $\mu \mathrm{m})\left(p=2.210^{-16}\right)$ and a significant increase of in silt percentage between $2001(6.69 \%)$ and 2007 $(13.50 \%)\left(p=2.210^{-16}\right)$. The evolution of the reef environment between 2001 and 2007 showed an increase in the size of the sand banks in the back-reef zone but a spectacular decrease of the sand sheet in the fore-reef zone.

\subsection{Biological and morphological changes}

\subsubsection{Reef general characteristics}

The mean reef coverage in $75 \times 75 \mathrm{~m}$ grid cell increased significantly between 2001 and 2007 $\left(36.0 \% \pm 14.1 \%\right.$ in 2007 versus $27.6 \pm 16.8$ in $\left.2001 ; t=4.91, p=110^{-4}\right)$. In 2007, elevation of the reef was at an average of $35.3 \pm 9.1 \mathrm{~cm}$, with the highest structures reaching around $75 \mathrm{~cm}$. Reef height was homogeneous between zones A, B and C in 2007, with $87 \%$ of values ranging between 25 and $50 \mathrm{~cm}$. Mean value $(35,3 \pm 9,1 \mathrm{~cm})$ did not significantly change from $2001(38,6 \pm 15.2 \mathrm{~cm}$; $Z=0.742, p=0.457$ ). The highest levels of fragmentation were observed in 2007, with the most severely fragmented located on the south-east zones of the reefs, facing the coast (Figure 4). The zone $A$ was the most fragmented part of the reef, with $68 \%$ of the grid squares having a fragmentation score equal to 0 or 2.5. Although the least fragmented zones were facing the mussel cultures, which was also the case in 2001, fragmentation levels significantly increased over the last years across the entire reef $\left(Z=5.03, p=110^{-4}\right)$. When sub-reefs were examined individually though, fragmentation was found to have significantly increased only on zone $B$ $\left(Z=4.46, p=110^{-4}\right)$.

\subsubsection{Colonisation by epifauna}

Despite the presence of blue mussel culture (Mytilus edulis) adjacent to the reef, mussels colonizing the structure belong to the species M. galloprovincialis. In 2007, the extent of spatial mussel coverage was significantly higher ( $22 \%$ of the grid squares, localized primarily in the southeast parts of sub-reefs $B$ and $C$, compared to $9 \%$ in 2001, $Z=2.16$ and $p=0.030$ ). With the exception of one grid square, M. galloprovincialis was totally absent of sub-reef $A$ in 2007. However, mussel density significantly decreased between 2001 (11.5 \pm 41.7 ind. $\mathrm{m}^{-2}$, with a 
maximum of 450 ind. $\left.\mathrm{m}^{-2}\right)$ and $2007\left(2.0 \pm 4.8\right.$ ind. $\mathrm{m}^{-2}$, with a maximum of 33 ind. $\mathrm{m}^{-2} ; \mathrm{Z}=2.54$ and $p=0.010)$ for the benefit of the Pacific oyster Crassostrea gigas. Spatial distribution patterns of these two mollusks looked opposite since high mussel densities were associated with low oyster densities, and vice-versa.

In 2001, oyster banks were essentially located in the south-west region of the reef, with densities reaching up to 40 ind. $\mathrm{m}^{-2}$ (Figure 5$)$. In 2007, their occurrence spread from sub-reefs $A(Z=1.15$, $p=0.249$, ns) to $B\left(6.68, p=110^{-4}\right)$. Sub-reef $C$ remained largely free of oysters, although rare spots were colonised by oysters, reaching densities of $60-90$ ind. $\mathrm{m}^{-2}$.

\subsubsection{Health status}

In $2001,35.2,38.5$ and $26.3 \%$ of total grid squares referred to bad, intermediate and good ecological statuses respectively, against to $38.9,25.7$ and $35.4 \%$ in 2007 . When all grid cells were considered, the average $\mathrm{HI}$ was 8.1 and 2.6 in 2001 and 2007 respectively $(Z=1.50, p=0.132)$, both intermediate ecological statuses. In 2001, sub-reefs B and C were in a better status (i.e. intermediate - average $\mathrm{HI}=9.6$ and 16.5 respectively) than sub-reef $\mathrm{A}$ (bad status - average $\mathrm{HI}=-$ 16.7, Figure 6). In 2007, health status decreased for sub-reefs A and B (overall bad status average $\mathrm{HI}=-26.3$ and -18 respectively). Conversely, sub-reef $\mathrm{C}$ reached a good status (average $\mathrm{HI}=22.0$ ) in 2007. In 2007, degradation status was highly correlated with the density of Crassostrea gigas $(-0.723)$

Statistical comparisons of $\mathrm{HI}$, performed between the two years (2001 and 2007) on common grid squares (i.e. 160) for each sub-reef, showed that changes were not statistically significant.

\section{Discussion}

There is a high contrast in biodiversity between the Sabellaria alveolata reefs, now recognized as a biodiversity hot-spot (Dubois et al., 2002), and the Macoma balthica sand community bordering these formations in the Bay of Mont-Saint-Michel which is known for its low species richness (Thorin, 2001). The argument for effective conservation management of $S$. alveolata reefs is therefore strongly supported, considering the vulnerability of the reef (Dubois et al., 2002).

\subsection{Evolution of the sedimentary environment}

The evolution of the reef environment is summarised in Figure 7. Additional field observations showed that the back-reef sand banks (called "la Grande Bosse" and "la Dune Plate", see Figure 3) rapidly grew and shifted landwards (50 to 100m.year ${ }^{-1}$, Bonnot-Courtois et al., 2004). Also, organic-rich mud deposits and moderately well sorted coarse-grained sands partly derived from the reef were accumulated in the back-reef zone. Associated reef-derived sand bodies were depleted in bioclasts contrary to the worm tubes forming the reef that play an actual role in storing of carbonate bioclasts (Noernberg et al., 2010). On the other hand, a slight south-westward expansion of the reef was noted. Sabellariid reefs generate sand bodies which consist of reefderived loose sands and the shape and distribution of these sand bodies are then controlled by local wave and current patterns (e.g. by tidal currents in the Bay of Mont-Saint-Michel). These elongated sand bars or spits (also figuratively named "tails") build out across tidal flats and ultimately connect with the main shore.

The Sainte-Anne reef here illustrates how organisms that do not produce carbonate may nevertheless form reefs in a siliclastic environment. The distribution and geometry of reef-related 
sand bodies are similar to those found in other regions (e.g. the Bay of Bourgneuf in the most southern part of Brittany). The S. alveolata colonies as well as the associated sand mound colonised by Lanice conchilega (another tube-building polychaete), indicate that annelids may modify the texture and the distribution of intertidal sediments because of their ability to trap and/or concentrate particles of specific mineralogy and grain-size (Callaway et al., 2010; Godet et al., 2011).

\subsection{Evolution of the reef health status}

In line with the observed sedimentary changes, the different descriptors of the reef health status, integrated in the $\mathrm{HI}$ calculus, suggest a degradative trend from 2001 to 2007 . The average HI value decreased only moderately from 8.1 to 2.6 between the sampling periods, but the trend differed between the reef sections. Sub-reefs $A$ and $B$ are strongly degraded and were therefore assigned bad statuses whereas sub-reef $\mathrm{C}$ evolved towards a better health status (from intermediate to good). Paradoxically, investigations of biodiversity associated to the different reef stages showed that the higher species richness is observed on the degraded sub-reef area, as well as completely different species assemblages, essentially because of the habitat fragmentation associated with changes in surface topography and increase in available space for new species to colonize the reef (Dubois et al., 2002). However, while degraded areas should not be considered as dead reef, the density of $S$. alveolata individuals is very low and not high enough to provide a basic maintenance of the reef. Biodiversity level is obviously not the only issue in terms of reef management objectives, especially knowing that the lower species richness occurs on platforms, when the reef reach its maximal height and higher tube density. In that perspective, a combination of all reef evolution stages is a way of assuring enough Sabellaria densities to allow maintenance and a proper renewal and evolution in reef structures. If the number of individuals is high enough to allow the Sabellaria population to grow and develop, degraded structures could then be the preferential substratum for $S$. alveolata larvae, also creating in the mean time an extension of the reef contours. Recent modelling results from Ayata et al. (2009) obtained from a 3D biophysical coupling developed in the Bay of Mont-Saint-Michel indicated that despite actual very low settlement rates (i.e. $<0.004 \%$ ), its hydrodynamic specificities could allow larval retention at the Bay scale and facilitate larval exchanges between the reef of Sainte-Anne and the one of Champeaux. In this context, any decrease in the reproductive outputs of the Sainte-Anne reef could adversely affect the sustainability of both reefs within the Bay of Mont-Saint-Michel. If the Sainte-Anne reef disappears, the larval supply from Champeaux might not be sufficient enough to both sustain itself and recolonise the Sainte-Anne reef (Ayata et al., 2009). The reef status in 2007 should then be considered as its minimal condition status and should not fall below this limit without jeopardizing its short-term survival.

\subsection{Understanding main factors adversely affecting reef health status}

Beyond the natural dynamics of the reef, several hypotheses are likely to explain the observed changes in the reef dynamics and its associated health status. Those factors relates to the colonization of the reef surface by epibionts and their recreational fishing as well to the implantation of new mussel farming structures their consequences on trophic competition within suspension-feeding species.

\subsubsection{Influence of reef colonisation by epibionts}

The stability of Sabellaria reefs is influenced not only by the stability of the substratum on which they settled, but also by their interactions with other species. Mussels, oysters and S. alveolata often occur together, and in many areas, one of them may be dominant at different times. Factors 
affecting this competitive interaction remain unclear. It has been reported by Perkins (1988) on reefs in Cumbria (North West England) that mussel recruitment was able to change the physionomy of the reef, and Cunningham et al. (1984) reported the existence of a Sabellaria/Mytilus succession. The development of shellfish farming in the Bay of Mont-SaintMichel, leads to high abundances of cultivated oysters (5000 tons) and mussels (12 000 tons) spatially concentrated in close areas to the reef. Such anthropogenic activities could indirectly affect Sabellaria reefs evolution by inducing high larval mortality and subsequently reducing larval supply because of filtration pressure as hypothesised in Dubois et al. (2007) and evidenced in wild mussel beds by Lehane and Davenport (2004) or Troost et al. (2008).

The Sainte-Anne reef is structurally heterogeneous, with healthy areas in close proximity to degraded zones. The degradation status of the reef in the south-western part is correlated with the presence of Crassostrea gigas, which has increased considerably in sub-reef B. Coming from the west part of the Bay where they are cultivated, oysters can easily colonise the Saint-Anne reef via the hydrodynamic circulation seeding larvae in this reef area. The Pacific oyster is not only a trophic competitor for S. alveolata (Dubois et al., 2003) but the high quantities of pseudo-faeces produced by oysters contribute to the increase in fine particles in the sediment. A study carried out on similar reefs in the Bay of Bourgneuf (France) showed however that the highest microphytobenthic biomass values are related to the presence of filter feeders (Mytilus $s p$ or Crassostrea gigas, Barillé, unpub. data).

Accumulations of oysters on the reef surface induce structural weakness due to their weight and ultimately contribute to the dislocation of balls and platforms (Dubois et al., 2002). But oyster's occurrence also comes with direct anthropogenic pressure generated oysters collection (e.g. destruction of reef blocs and surface scrapping) and associated trampling. Managing anthropogenic activities close to the reef is a major issue that needs to be address by decisionmakers. The collection of species such as Venerupis saxatilis or the scallop Chlamys varia which live in reef crevices, ultimately leading to reef alteration, should be managed too. Gleaning with gears such as iron bars, chisels..., evidently break ball-shape structures and platforms and alter the reef structure. The destruction of the reef induces a fragmentation of the habitat. The conservation challenge is to avoid an irreversible habitat alteration and the decline of the reef which would induce a loss of biological diversity at large scale, and have dramatic consequences for other marine habitats as reported by Thrush et al. (2008).

\subsubsection{Implantation of new mussel farming structures}

A modification of the shellfish farming scheme was completed in 2006. Farming sites along the western portion were abandoned on behalf of more productive sites located to the North of SainteAnne reef. A pre-impact study of this new scheme has shown that the current speed would decrease downstream of the new installations facing the reef (Salomon, 2000). A few years after the change in shellfish structure, as modelled, we observed a decrease of mean grain-size, higher in the fore-reef area. The new scheme induced several problems. Firstly, the increase of suspended particulate matter (organic and inorganic) disturbs the filtration rate of $S$. alveolata (Dubois et al., 2009) inabrading feeding organs and clogging up the tubes. Secondly, the decrease of current velocity increases the sedimentation and decreases the sand grain re-suspension. This leads to a decrease in tube-building activity, since the tubes are built by the polychaetes by catching sand particles drifting near their tube aperture.

\subsubsection{Influence of trophic depletion}

To understand the functioning of the trophic food wed in the Bay of Mont-Saint-Michel, an ecological model of the Bay was developed by Cugier et al. (2010) to couple a 2D hydrosedimentary model with two biological models for primary production and filter-feeder filtration 
activity. Results dealing with S. alveolata reef of Sainte-Anne showed that, after the implantation of new structures for mussel cultivation from 2004 to 2006 in front of the reef, a large decrease of mussel growth would occur due to a lack of food which persists just in front of the reef. This depletion may also affect directly S. alveolata growth and fecundity and could explain part of the reef regression.

\section{Conclusion}

Reef-forming organisms are recognized as keystone species which provide complex structural habitats of high biodiversity [e.g. S. alveolata (Dubois et al., 2002); mussel beds (Saier, 2002); Limaria hians (Hall-Spencer \& Moore, 2000).... . As shown in S. spinulosa aggregations (Hendricks \& Foster-Smith, 2006), S. alveolata aggregations enhance biodiversity compared to the surrounding sediment and contribute to the distinctness of the reef habitat as well as imparting a greater significance to the habitat in terms of conservation.

Contrary to the United Kingdom, where S. alveolata reefs have benefited from a Biodiversity Action Plan (BAP) since 1994 (http://www.ukbap.org.uk/UKPriorityHabitats.aspx), no global measures for protection or management of this habitat were taken in France. The unique extension of these reefs in the Bay of Mont-Saint-Michel is responsible for the recent rise in awareness of the necessity of their conservation within the region. However, the conservation of Sabellaria reefs only became a priority when the structures were included in a designated Natura 2000 site in the Bay (FR 2500077). Measures to achieve favourable conservation status (FCS) according to the Habitats Directive were drafted in 2009 and include: (1) regulation of the pedestrian and motorised circulation on the reefs and (2) promotion of sustainable gleaning techniques on the reefs and their vicinity. These measures will need environmental monitoring and information to make users aware of this exceptional biological heritage.

\section{Acknowledgements}

We wish to thank Carey G. Gelpi (Louisiana State University) and Amelia Curd (IFREMER) for English editing as well as anonymous reviewers and $\operatorname{Pr} \mathrm{S}$. Hawkins for their helpful comments.

\section{References}

Achary, GPK. 1974. Polychaete of the family Sabellariidae with special reference to their intertidal habitat. Proceedings of the Indian Natural Science Academy 38: 442-455.

Ayata SD, Ellien C, Dumas F, Dubois S Thiébaut E. 2009. Modelling larval dispersal and settlement of the reef-building polychaete Sabellaria alveolata: role of hydroclimatic processes on the sustainability of biogenic reefs. Continental Shelf Research 29: 1605-1623.

Blott SJ, Pye K. 2001. GRADISTAT: a grain size distribution and statistics package for the analysis of unconsolidated sediments. Earth Surface Processes and Landforms 26: 1237-1248.

Bonnot-Courtois C, Bassoulet P, Tessier B, Cayocca F, Le Hir P, Baltzer A. 2008. Remaniements sédimentaires superficiels sur l'estran occidental de la baie du Mont-Saint-Michel. European Journal of Environmental and Civil Engineering 12: 51-65. 
Bonnot-Courtois C, Fournier J, Dréau A. 2004. Recent morphodynamics of shell banks in the western part of Mont-Saint-Michel Bay (France). Géomorphologie: relief, processus, environnement 04(1): 65-80.

Callaway R, Desroy N, Dubois S, Fournier J, Frost M, Godet L, Hendrick V, Rabaut M. 2010. Ephemeral bio-engineers or reef builders: how stable are aggregations of the tube worm Lanice conchilega (Pallas, 1766)? Integrative and Comparative Biology 50(2): 237-250.

Cranfield HJ. 2003. Effects of oyster dredging on the distribution of bryozoan biogenic reefs and associated sediments in Foveaux Strait, southern New Zealand. Continental Shelf Research 23: 1337-1357.

Cugier P, Struski C, Blanchard M, Mazurié J, Pouvreau S, Olivier F, Trigui RJ Thiébaut E. 2010. Assessing the role of benthic filter-feeders on phytoplanktonic production in a shellfish farming site: Mont-Saint-Michel Bay, France. Journal of Marine Systems 82: 21-34.

Cunningham PN, Hawkins SJ, Jones HD Burrows MT. 1984. The biogeography and ecology of Sabellaria alveolata. Nature Conservancy Council CSD report N 535.

Davenport J, Smith RJJ Packer M. 2000. Mussels Mytilus edulis: significant consumers and destroyers of mesozooplankton. Marine Ecology Progress Series 198: 131-137.

De Voogd NJ. 2006. The mariculture potential of the indonesian reef-dwelling sponge Callyspongia (Euplacella) biru : growth, survival and bioactive compounds. Aquaculture 262: 5464.

Dubois S. 2003. Ecologie des formations récifales à Sabellaria alveolata (L.) : valeur fonctionnelle et patrimoniale. Muséum National d'Histoire Naturelle (PhD thesis).

Dubois S, Retière C, Olivier F. 2002. Biodiversity associated with Sabellaria alveolata (Polychaeta: Sabellaridae) reefs : effects of human disturbances. Journal of Marine Biological Association of the United Kingdom 82:817-826.

Dubois S, Barille L, Retiere C. 2003. Efficiency of particle retention and clearance rate in the polychaete Sabellaria alveolata L. Comptes Rendus Biologies 326: 413-421.

Dubois S, Barillé L, Cognie B, Beninger PG. 2005. Particle capture and processing mechanism in Sabellaria Iveolata (Polychaeta: Sabellariidae). Marine Ecology Progress Series, 301: 159-171.

Dubois S, Commito JA, Olivier F, Retiere C. 2006. Effects of epibionts on Sabellaria alveolata (L.) biogenic reefs and their associated fauna in the Bay of Mont-Saint-Michel. Estuarine Coastal and Shelf Science 68: 635-646.

Dubois S, Comtet T, Retière C, Thiébaut E. 2007. Distribution and retention of Sabellaria alveolata larvae (Polychaeta: Sabellariidae) in the Bay of Mont-Saint-Michel, France. Marine Ecology Progress Series 344:15-28.

Dubois S, Barille L, Cognie B. 2009. Feeding response of the polychaete Sabellaria alveolata (Sabellariidae) to changes in seston concentration. Journal of Experimental Marine Biology and Ecology 376 : 94-101.

Eckrich CE, Holmquist JG. 2000. Trampling in a seagrass assemblage : direct effects, response of associated fauna, and the role of substrate characteristics. Marine Ecology Progress Series 201:199-209. 
Folk RL, Ward WC. 1957. Brazos river bar: a study of significance of grain size parameters. Journal of Sedimentary Petrology 27:3-26.

Fournier J, Etienne S, Le Cam JB. 2010. Inter- and intraspecific variability in the chemical composition of the mineral phase of cements from several tube-building polychaetes. Geobios 43(2): 191-200.

Godet L, Fournier J, Jaffré M, Desroy N. 2011. Influence of stability and fragmentation of a wormreef on benthic macrofauna. Estuarine, Coastal and Shelf Science 92(3): 472-479.

Godet L, Fournier J, Toupoint N, Olivier F. 2009. Mapping and monitoring intertidal benthic habitats: a review of techniques and proposal of a new visual methodology for the European coasts. Progress in Physical Geography 33(3): 378-402.

Godet L, Toupoint N, Olivier F, Fournier J, Retière C. 2008. Considering the functional value of common marine species as a conservation stake. The case of the sandmason worm Lanice conchilega (Annelid Polychaeta, Pallas 1766) beds. Ambio: A Journal of the Human Environment 37(5):347-355.

Hall-Spencer JM, Moore PG. 2000. Limaria hians (Mollusca: Limacea); a neglected reef-forming keystone species. Aquatic Conservation: Marine and Freshwater Ecosystems 10: 267-277.

Hendrick VJ, Foster-Smith RL. 2006. Sabellaria spinulosa reef: a scoring system for evaluation "reefiness" in the context of the Habitat Directive. Journal of Marine Association of the United Kingdom 86: 665-677.

Holt TJ, Rees El, Hawkins SJ, Seed R. 1998. Biogenic reefs volume IX). An overview of dynamic and sensitivity characteristics for conservation management of marine SACs. Scottish Association for Marine Science (UK Marine SACs Project).

Le Cam JB, Fournier J, Etienne S, Couden J. 2011. The strength of biogenic sand reefs: Viscoelastic behaviour of cement secreted by the tube building polychaete Sabellaria alveolata, Linnaeus, 1767. Estuarine, Coastal and Shelf Science 91: 333-339.

Lehane C, Davenport J. 2004. Ingestion of bivalve larvae by Mytilus edulis: experimental and field demonstrations of larviphagy in farmed blue mussels. Marine Biology 145: 101-107.

Moore CG, Saunders GR, Harries DB. 1998. The status and ecology of reefs of Serpula vermicularis L. (Polychaeta: Serpulidae) in Scotland. Aquatic Conservation: Freshwater Ecosystems 8: 645-656.

Noernberg M. Fournier J, Dubois S. Populus J. 2010. The use of airborne laser altimetry to estimate Sabellaria alveolata reefs volume in tidal flats environment. Estuarine, Coastal and Shelf Science 90(2): 93-102.

Pawlick JR. 1998. Larval settlement and metamorphosis of two gregarious Sabellariid Polychaetes: Sabellaria alveolata compared with Phragmatopoma californica. Journal of Marine Biological Association of United Kingdom 68: 101-124.

Perkins EJ. 1988. Fourteenth report to the Cumbria Sea-Fisheries Committee. Solway Firth survey $-1^{\text {st }}$ July 1987 to $30^{\text {th }}$ June 1988. Solway Marine Investigations, Maryport, Cumbria.

R Development Core Team. 2011. R: A Language and Environment for Statistical Computing. R Foundation for Statistical Computing, Vienna, Austria. ISBN 3-900051-07-0, URL http://www.Rproject.org/ 
Rodney WS, Paynter KT. 2006. Comparisons of macrofaunal assemblages on restored and nonrestored oyster reefs in mesohaline regions of Chesapeake Bay in Maryland. Journal of Experimental Biology and Ecology 335: 39-51.

Saier B. 2002. Subtidal and intertidal mussel beds (Mytilus edulis L .) in the Wadden Sea: diversity differences of associated epifauna. Helgoland Marine Research 56: 44-50.

Salomon JP. 2000. Etude d'impact de la restructuration conchylicole en baie du Mont- SaintMichel. Etude courantologique et sédimentologique. Rapport Section Régionale de la Conchyliculture de Bretagne Nord, Brest.

Scherrer B. 1984. Biostatistique. Gaëtan-Morin, Chicoutimi, Québec.

Thorin S, Radureau M, Feunteun E Lefeuvre JC. 2001. Preliminary results on a high east-west gradient in the macrozoobenthic community structure of the macrotidal Mont-Saint-Michel Bay. Continental Shelf Research 2: 2167-2183.

Thrush SF, Halliday J, Hewitt JE, Lohrer AM. 2008. The effects of habitat loss, fragmentation, and community homogenization on resilience in estuaries. Ecological Applications 18: 12-21.

Troost K, Kamermans P, Wolff WJ. 2008. Larviphagy in native bivalves and in introduced oyster. Journal of Sea Research 60: 157-163.

Wilson DP. 1929. The larvae of the British Sabellarian. Journal of Marine Biological Association of United Kingdon, 16: 221-268.

Wilson DP. 1968. The settlement behaviour of the larvae of Sabellaria alveolata (L.). Journal of Marine Biological Association of United Kingdon, 48: 387-435.

Wilson DP. 1970. Additional observations on larval growth and settlement of Sabellaria alveolata. Journal of Marine Biological Association of United Kingdon, 50: 1-31.

Wilson DP. 1971. Sabellaria colonies at Duckpool, North Cornwall, 1961-1970. Journal of Marine Biological Association of United Kingdon, 51: 509-580.

\section{Tables}

Table 1: Ecological Quality Ratio (EQR) values and ecological status associated with the HI index. Theoretical minimum and maximal values are of -200 and 110.

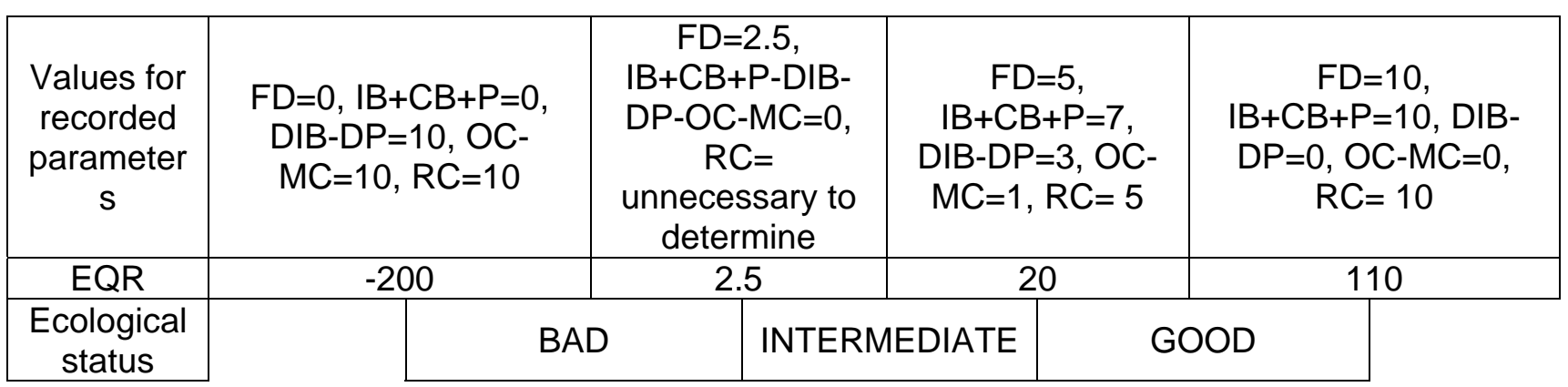


Table 2: Results of paired $t$-tests between reef sectors and between years for surrounding sediments of the Sainte-Anne reef with $p$ value

\begin{tabular}{|c|c|c|c|c|c|}
\hline & $x$ & $\sigma$ & $t$ & $\mathrm{dl}$ & $p$ \\
\hline \multicolumn{6}{|l|}{ Fore-reef } \\
\hline $\mathrm{M}_{\mathrm{G}} \mu \mathrm{m}(2001)$ & 753.52 & 310.45 & \multirow{2}{*}{-19.3511} & \multirow{2}{*}{21} & \multirow{2}{*}{$=7.246 \mathrm{e}-15$} \\
\hline$M_{G} \mu \mathrm{m}(2007)$ & 369.45 & 276.89 & & & \\
\hline$\%<63 \mu \mathrm{m}(2001)$ & 3 & 6.23 & \multirow{2}{*}{-822.664} & \multirow{2}{*}{21} & \multirow{2}{*}{$<2.2 \mathrm{e}-16$} \\
\hline$\%<63 \mu \mathrm{m}(2007)$ & 8.39 & 15.28 & & & \\
\hline \multicolumn{6}{|l|}{ Reef } \\
\hline$M_{G} \mu m(2001)$ & 703.91 & 483.45 & \multirow{2}{*}{-15.8254} & \multirow{2}{*}{29} & \multirow{2}{*}{$=8.37 \mathrm{e}-16$} \\
\hline$M_{G} \mu m(2007)$ & 693.14 & 434.76 & & & \\
\hline$\%<63 \mu \mathrm{m}(2001)$ & 4.25 & 13.58 & \multirow{2}{*}{-768.4201} & \multirow{2}{*}{29} & \multirow{2}{*}{$<2.2 \mathrm{e}-16$} \\
\hline$\%<63 \mu \mathrm{m}(2007)$ & 5.19 & 14.91 & & & \\
\hline \multicolumn{6}{|l|}{ Back-reef } \\
\hline$M_{G} \mu m(2001)$ & 313.56 & 191.27 & \multirow{2}{*}{-38.3135} & \multirow{2}{*}{23} & \multirow{2}{*}{$<2.2 \mathrm{e}-16$} \\
\hline$M_{G} \mu \mathrm{m}(2007)$ & 265.12 & 249.61 & & & \\
\hline$\%<63 \mu \mathrm{m}(2001)$ & 6.69 & 13.79 & \multirow{2}{*}{-552.492} & \multirow{2}{*}{23} & \multirow{2}{*}{$<2.2 \mathrm{e}-16$} \\
\hline$\%<63 \mu \mathrm{m}(2007)$ & 13.50 & 21.52 & & & \\
\hline
\end{tabular}


Figure 1: Overview of the Bay of Mont-Saint-Michel and location of the Sainte-Anne reef. Mussel culture areas represented by dotted lines correspond to recently added plots (2003)

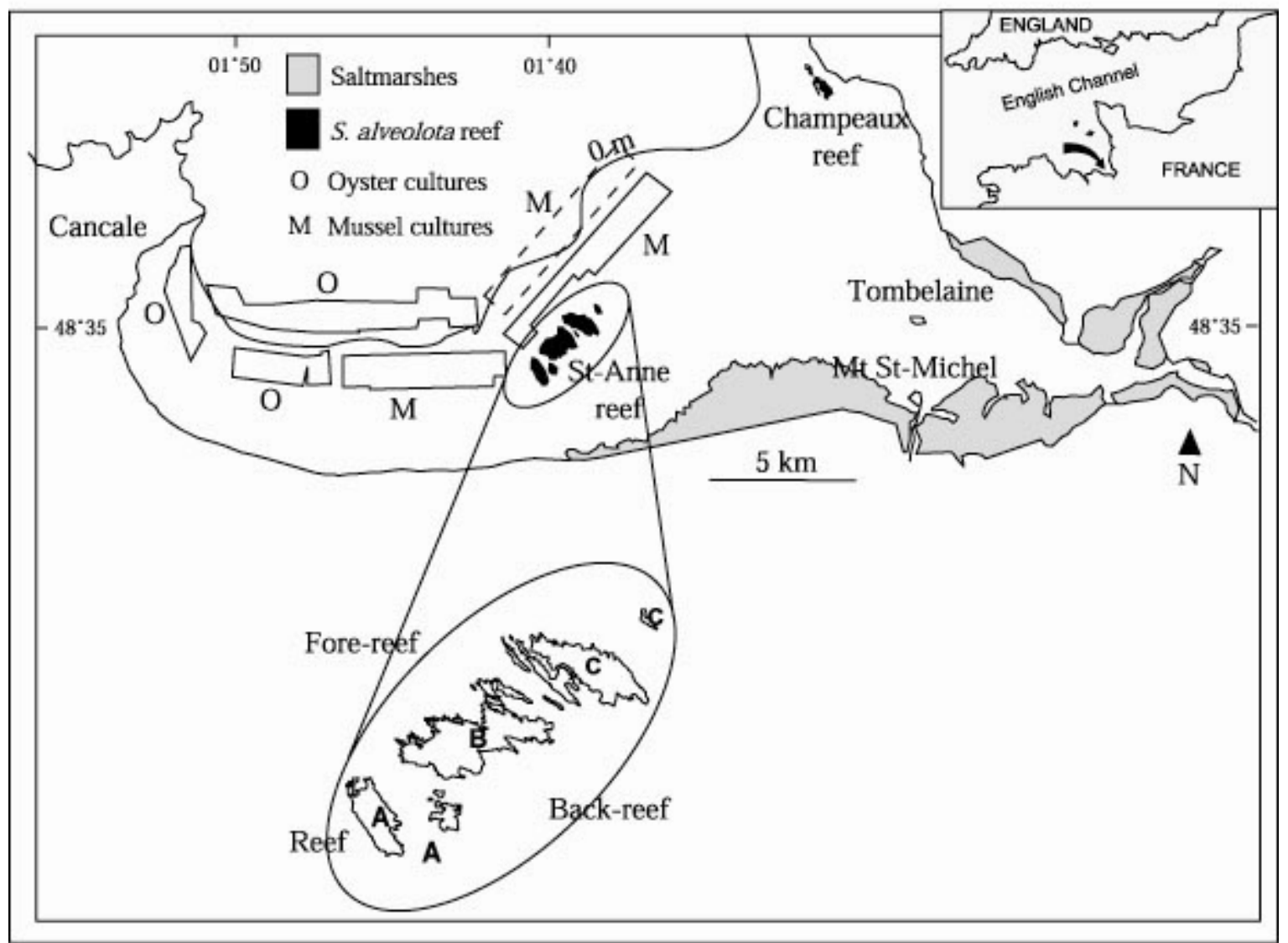

Figure 2: Fragmentation scale of Sabellaria alveolata reef and associated score. Values assigned to stages are used for the HI estimates

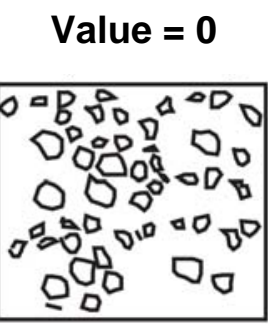

2.5

5

7.5 10
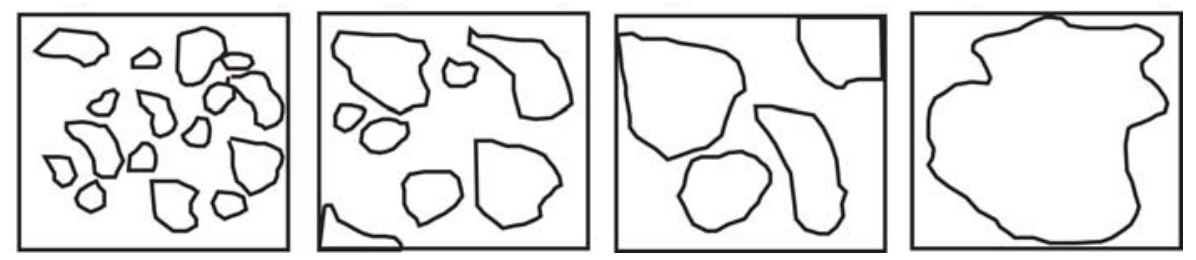
Figure 3: Sedimentary changes between 2001 and 2007 observed at the Sainte-Anne reef

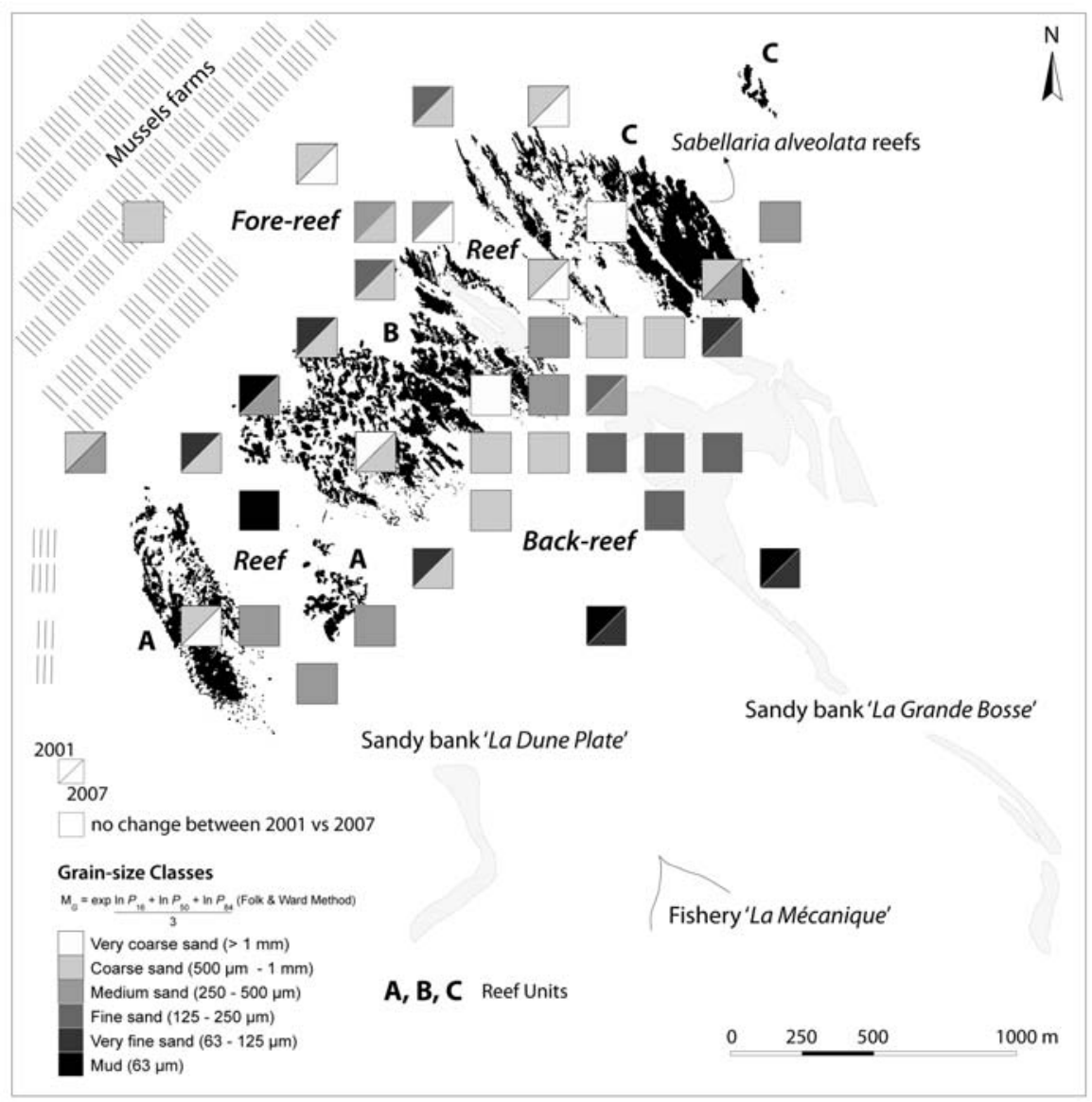


Figure 4: Fragmentation levels observed in 2001 and 2007 (ND= no data). Dotted lines (top left corner) represent mussel bouchots.

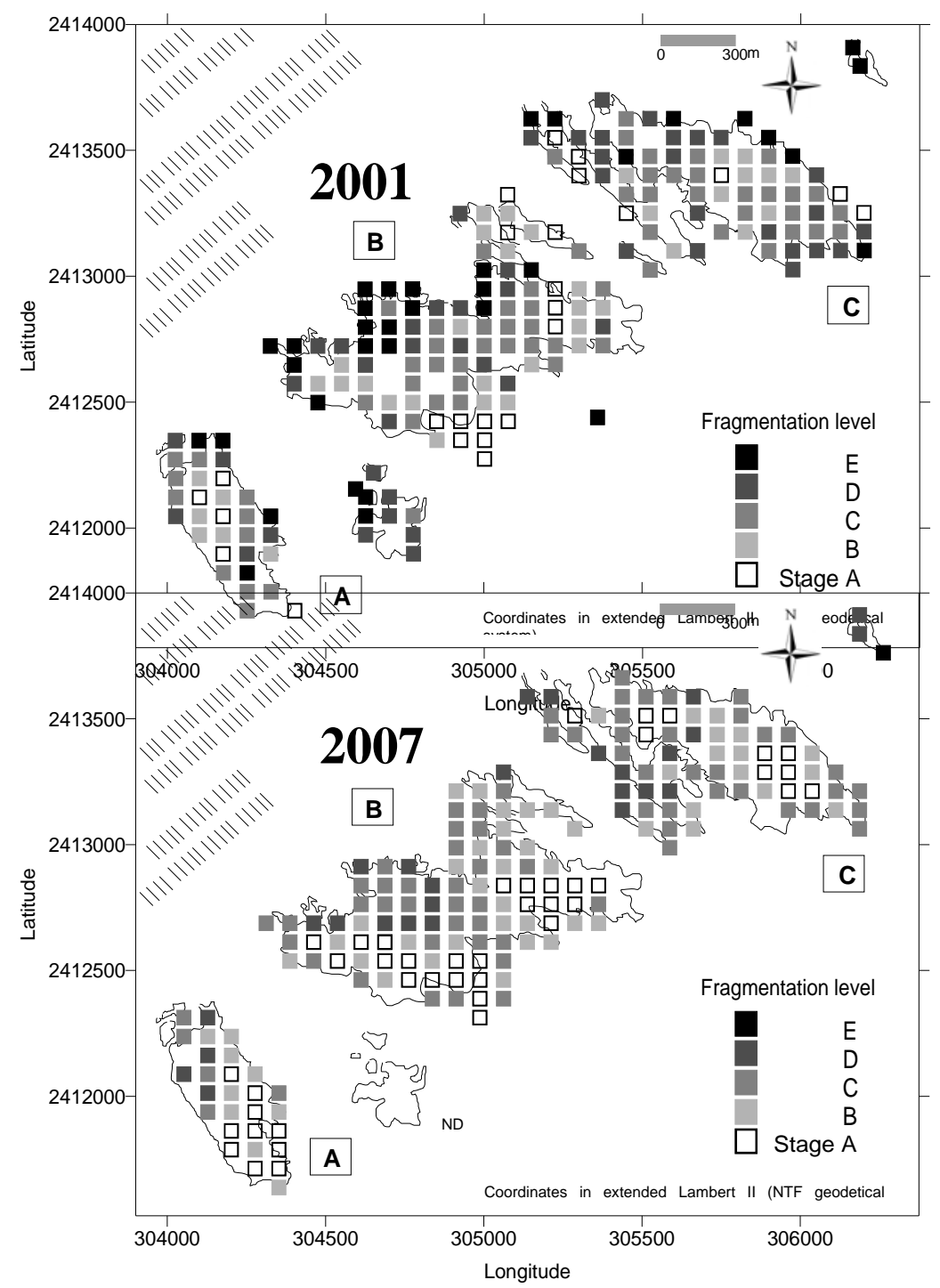


Figure 5: Oyster density (ind. $\mathrm{m}^{-2}$ ) in 2001 and 2007 (ND= no data). Dotted lines (top left corner) represent mussel bouchots.

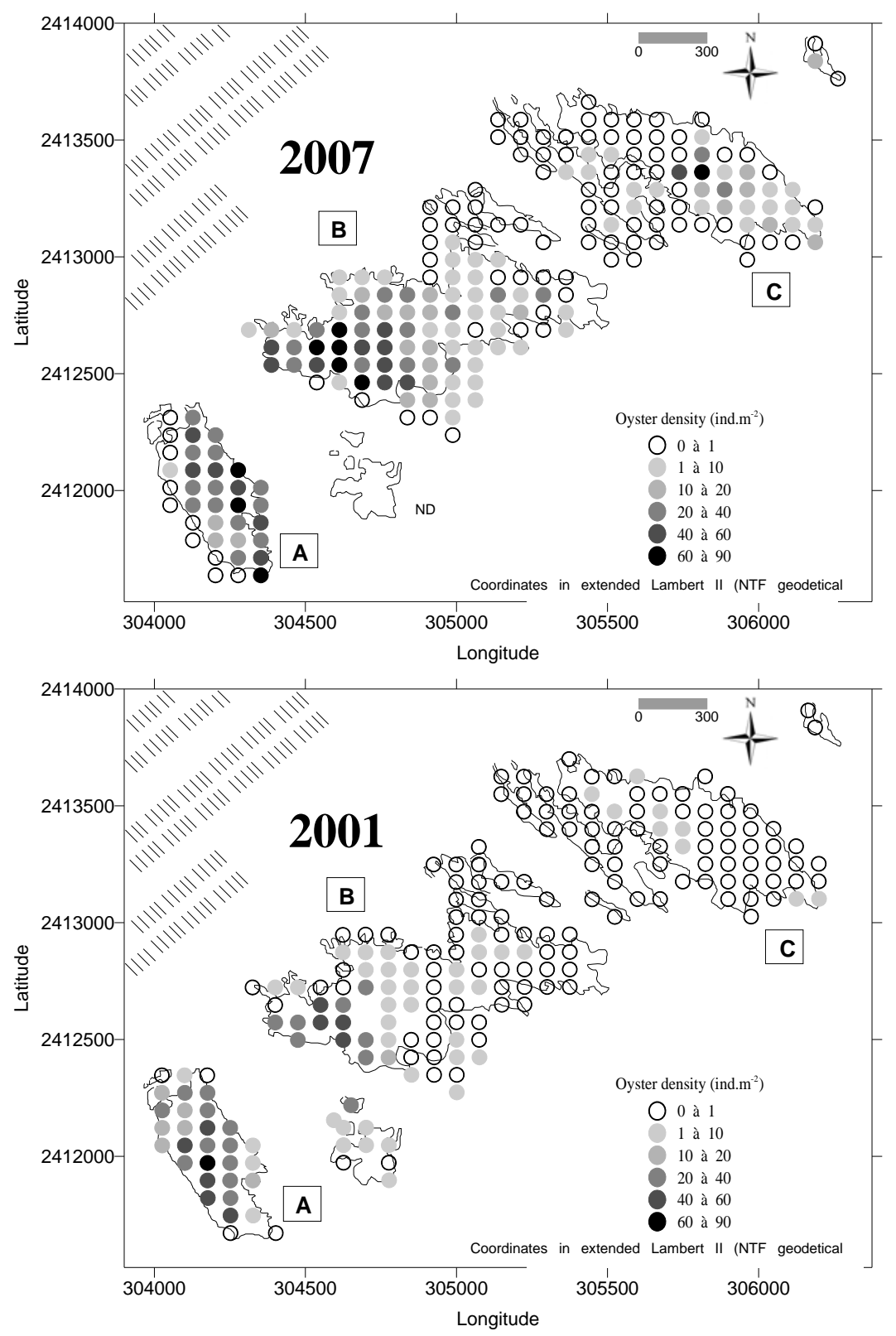


Figure 6: Health index observed in 2001 and 2007 (ND= no data). Dotted lines (top left corner) represent mussel bouchots.
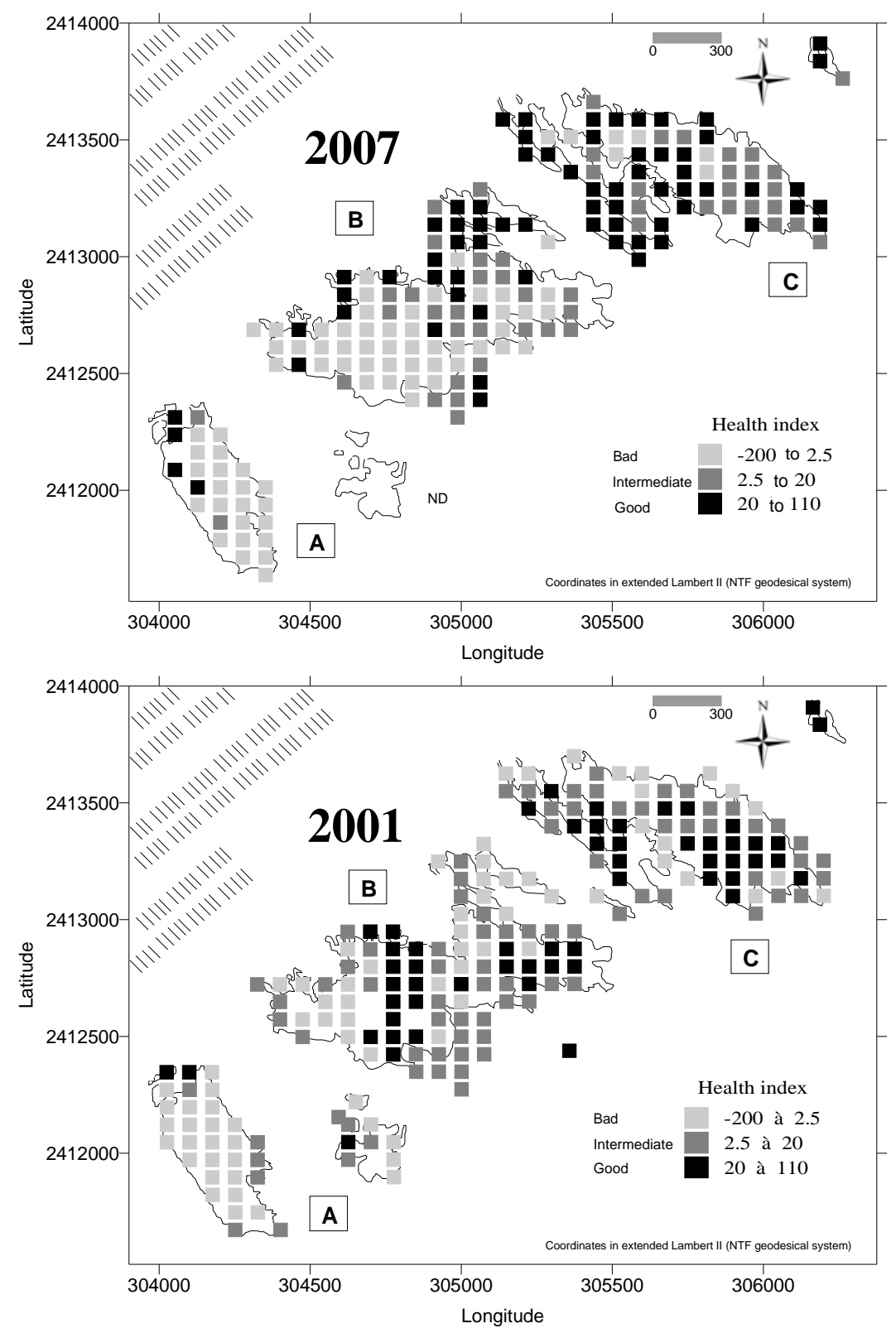
Figure 7: Biosedimentological model of a Sabellaria alveolata reef as based on the SainteAnne reef of the Bay of Mont-Saint-Michel.

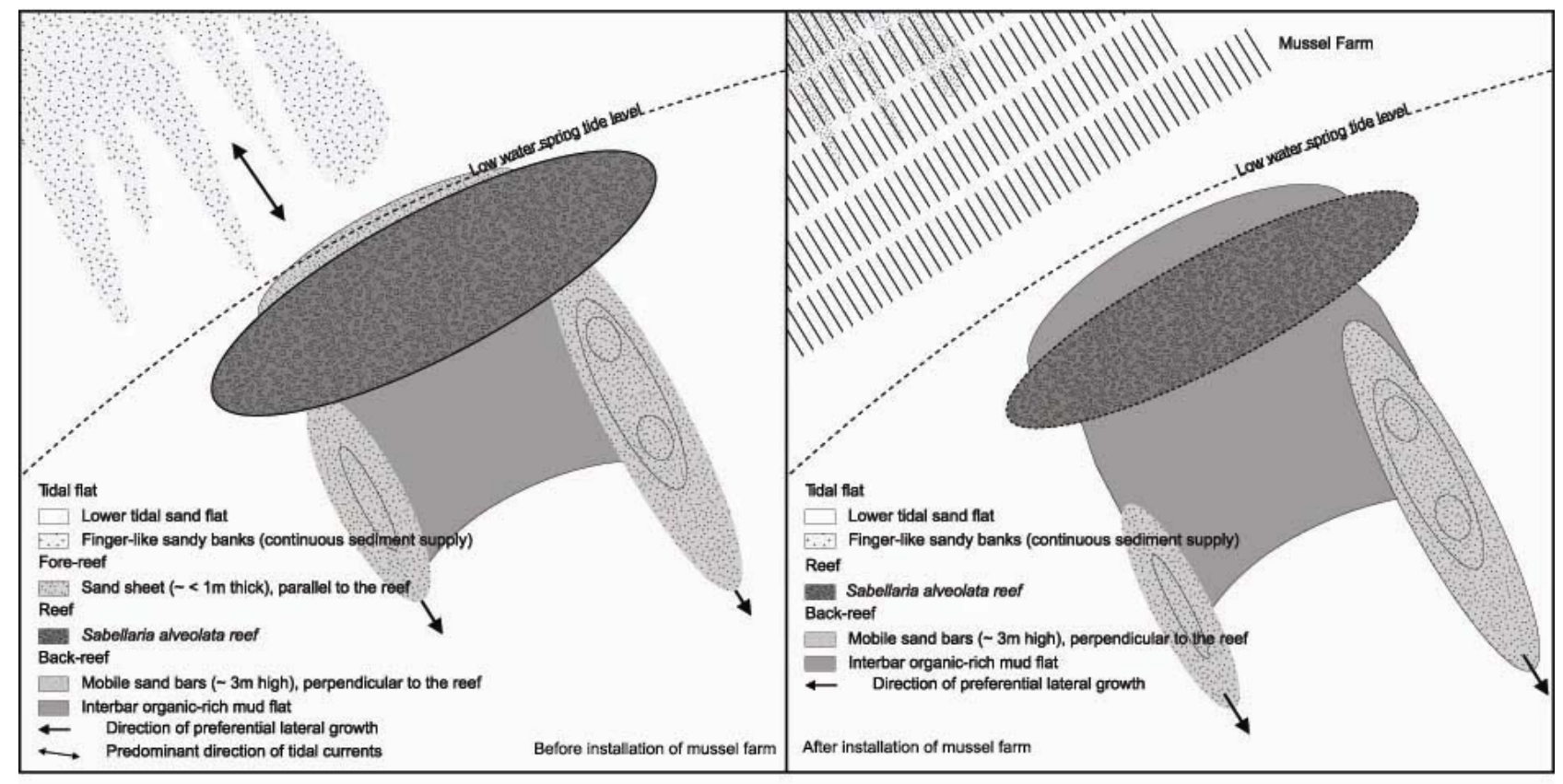

